\title{
Supervision of Large Complex Banking Organizations
}

Lisa M. DeFerrari and David E. Palmer, of the Board's Division of Banking Supervision and Regulation, prepared this article.

Over the past decade, the long-term trends of consolidation and innovation in the U.S. banking system have intensified. Today a large proportion of assets held by U.S. banking organizations is concentrated in a small number of companies, and U.S. banking organizations have integrated into their product mix activities that extend well beyond traditional deposittaking and lending. As a result of these developments, there is a small number of banking organizations that are larger and engage in a wider array of financial activities than at any time in recent history.

Banking supervisors have responded to these changes by adapting their approaches to supervision so that they continue to be aligned with the way financial organizations structure and manage their business activities. These newer approaches-collectively referred to as risk-focused supervision-are designed to focus the greatest amount of supervisory attention on the business areas that represent the greatest risk to a banking organization's overall condition.

The Federal Reserve began to implement a structured, more formal program of risk-focused supervision in the early 1990s, and that program continues to evolve as the banking system itself continues to change. Since the mid-1990s, the Federal Reserve has devoted particular attention to developing and implementing a program for the supervision of the largest, most complex banking organizations, or LCBOs. Given the speed with which the risk profiles of these institutions can change, the LCBO supervision program incorporates both a more continuous supervision process than in the past and a greater emphasis on the evaluation of banking organizations' internal systems and controls for managing risk.

\section{DEVELOPMENT OF THE PROGRAM FOR LCBOS}

\section{Trends in the Banking Industry}

Since 1989, the U.S. banking industry has undergone both consolidation in assets and expansion in the range of financial activities conducted, an extension of long-term trends. From 1989 to 1999, the number of independent banking organizations in the United States fell from 9,500 to $6,800 .{ }^{1}$ Over the same period, total assets held by these banking organizations rose nearly 50 percent in real terms (chart 1 ). A related trend is that the banking system's assets have become even more concentrated than before in the largest banking organizations. Specifically, the share of total assets held by the fifty largest U.S. banking organizations rose from 55 percent in 1989 to 74 percent in 1999; the share held by the ten largest grew from 26 percent to 49 percent (chart 2).

Expansion in the range of financial activities of U.S. banking organizations is reflected in an increase both in the notional amount of derivatives contracts and in the size of nonbank subsidiaries. A small number of institutions are responsible for the largest portion of derivatives activity of U.S. banking organi-

1. Included are all bank holding companies and all independent banks (with no holding company). Notably, most of the consolidation in the banking system has occurred as the result of mergers and acquisitions, but bank failures at the beginning of the period also played a role. For more detail, see Stephen A. Rhoades, Bank Mergers and Banking Structure in the United States, 1980-98, Staff Studies 174 (Board of Governors of the Federal Reserve System, August 2000).

1. Number and total assets of U.S. banking organizations, 1989-99

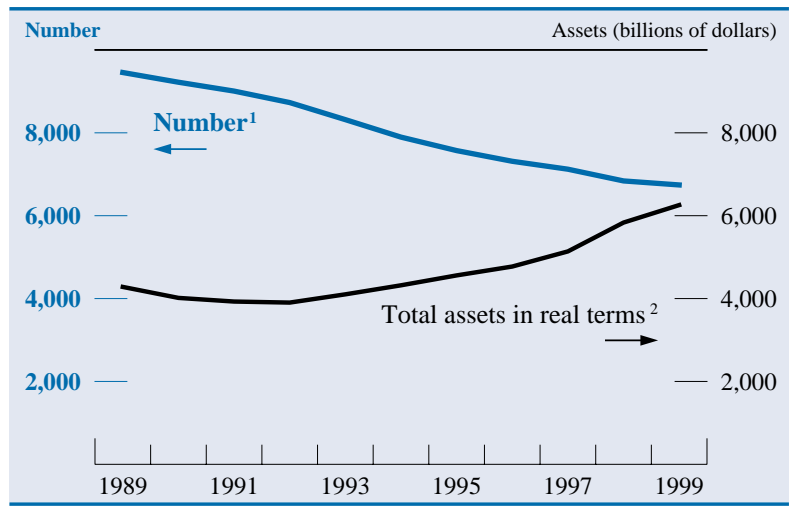

1. Includes all bank holding companies and independent banks with no holding company.

2. Adjusted by the GDP deflator (base year $=1996$ ). 
2. Share of total banking assets held by the fifty largest U.S. banking organizations, selected years, 1989-99

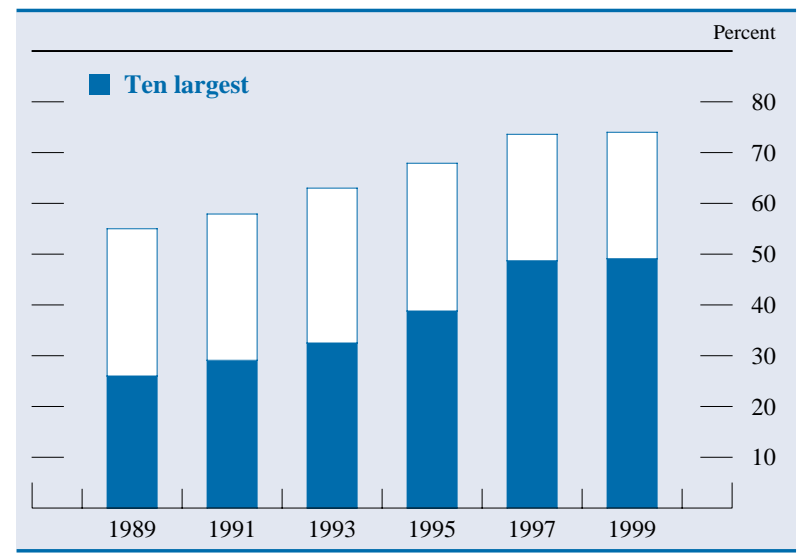

zations, with the ten largest institutions accounting for nearly 95 percent of the total notional amount. Growth in the assets of nonbank subsidiaries of U.S. banking organizations over the past decade reflects in large part a significant expansion in the securities activities of the largest organizations. Total assets of nonbank subsidiaries held by the largest fifty banking organizations now represent nearly a quarter of their total consolidated assets, and the largest ten companies account for the greatest proportion of these nonbank assets. ${ }^{2}$

Many factors account for the increase in asset concentration at the largest U.S. banking organizations as well as the broadening of the range of their financial activities during the 1990s. These factors include increased competition in financial markets, improvements in information technology, the lifting of restrictions on interstate branching, some easing of regulatory restrictions on securities activities, the globalization of economic activity, and an effort by banking organizations to diversify revenue sources to mitigate cyclical effects on core banking activities, such as lending and deposit-taking. ${ }^{3}$

These trends are expected to continue, particularly given recent changes in U.S. banking law. During the six decades before 1999, U.S. banking organizations were subject to the provisions of the Banking Act of 1933, commonly referred to as the Glass-Steagall Act, which prohibited U.S. banks from being affili-

2. For a few of the fifty largest companies, data on total nonbanking assets were not available.

3. For a useful survey on this topic, see Allen N. Berger, Rebecca S. Demsetz, and Philip E. Strahan, "The Consolidation of the Financial Services Industry: Causes, Consequences, and Implications for the Future," Journal of Banking and Finance, vol. 23 (February 1999), pp. 135-94. ated with firms engaged principally in corporate securities underwriting and dealing. Thus, the banking business and the securities business were effectively separated. Starting in the mid-1980s, this separation began to diminish as some U.S. bank holding companies established securities subsidiaries, subject to revenue and other limits to prevent violation of the Glass-Steagall Act. ${ }^{4}$ U.S. banking organizations, however, were still generally prohibited from engaging in insurance underwriting activities. The GrammLeach-Bliley Act of 1999 eliminated the separation of financial activities, allowing U.S. banking organizations with well-capitalized and well-managed bank subsidiaries to engage in both securities and insurance underwriting activities through separate subsidiaries. Banking organizations are now allowed to own securities and insurance companies and vice versa.

\section{Supervisory Responses}

Supervisory programs for state member banks and bank holding companies are implemented by individual Reserve Banks under policies and procedures issued by the Federal Reserve Board. 5 Historically, the Reserve Banks generally used local supervisory staff for examinations and inspections, which, for the most part, were focused on legal entities, such as banks, Edge corporations, or bank holding companies. The examinations and inspections were conducted once a year in most cases, and, subsequently, a rating was issued for the entity examined. There was usually little supervisory activity focused on the examined entity during the remainder of the year unless a crisis arose or the examination revealed material problems that required continued attention by supervisors. Ratings were arrived at using an approach that placed a great deal of emphasis on the valuation of assets, particularly the loan portfolio, while also taking into consideration assessments of other factors, including capital, earnings, liquidity, and management.

4. For example, these so-called section 20 securities subsidiaries (referring to section 20 of the Glass-Steagall Act) were allowed to have only a certain percentage of their revenue stem from securities activities normally not allowed in a commercial bank-"bankineligible" activities_-and were also limited outright from conducting other activities.

5. The type of charter that a U.S. bank holds determines its primary supervisor. For nationally chartered banks, the primary supervisor is the Office of the Comptroller of the Currency; for state-chartered banks that are members of the Federal Reserve System, it is the Federal Reserve and the respective state; and for state-chartered banks that are not members of the Federal Reserve, it is the Federal Deposit Insurance Corporation and the respective state. The Federal Reserve also supervises bank holding companies and Edge corporations. 


\section{Key Milestones in Risk-Focused Supervision}

As with most large-scale supervisory efforts, the development of risk-focused supervision and of the LCBO program has progressed in stages. The formal elements of the program's policy development include a number of supervision and regulation (SR) letters, published by the Division of Banking Supervision and Regulation at the Federal Reserve Board. In general, these SR letters provide a way for the Board to communicate supervisory policies to its supervisory personnel, to the banking industry, to other market participants, and to the general public. ${ }^{1}$ The SR letters related to risk-focused supervision and the LCBO program include the following.

- SR 95-22: Enhanced Framework for Supervising the U.S. Operations of Foreign Banking Organizations. Details a risk-focused supervision program developed by the banking supervisory authorities that have supervisory and examination responsibilities for the U.S. operations of foreign banking organizations.

- SR 95-51: Rating the Adequacy of Risk Management Processes and Internal Controls at State Member Banks and Bank Holding Companies. Instructs examiners to shift more of their focus to risk-management processes and internal controls in recognition that new technologies, product innovation, and the size and speed of financial transactions have changed the nature of financial markets.

- SR 96-14: Risk-Focused Safety and Soundness Examinations and Inspections. Outlines the elements of riskfocused examinations and inspections, which focus particular attention on the most important risks facing an institution and evaluate lower-risk businesses less intensively.

- SR 97-24: Risk-Focused Framework for Supervision of Large Complex Institutions. Describes the framework of a risk-focused supervision program for institutions with more than $\$ 1$ billion in assets. The details of the framework, including examination and inspection procedures, are contained in an attachment, "Framework for the Risk-Focused Supervision of Large Complex Organizations."

1. The SR letters are available at www.federalreserve.gov/boarddocs/ srletters. The first two digits of each letter indicate the year of issuance, the second, the sequence of its issuance that year.
- SR 98-13: Enhancements to the Interagency Program for Supervising the U.S. Operations of Foreign Banking Organizations. Describes improvements to the interagency risk-focused supervision program for the U.S. operations of foreign banking organizations.

- SR 98-25: Sound Credit Risk Management and the Use of Internal Credit Risk Ratings at Large Banking Organizations. Guides supervisors in their evaluation of creditrisk-management systems and offers examples of sound practices.

- SR 99-15: Risk-Focused Supervision of Large Complex Banking Organizations. Applies the risk-focused supervision framework to LCBOs and emphasizes the challenges inherent in evaluating their internal control and riskmanagement systems.

- SR 99-18: Assessing Capital Adequacy in Relation to Risk at Large Complex Banking Organizations and Others with Complex Risk Profiles. Directs supervisors to evaluate banking organizations' internal capital management processes to determine whether they meaningfully tie the identification, monitoring, and evaluation of risk to the determination of the institutions' capital needs. ${ }^{2}$

- SR 00-13: Framework for Financial Holding Company Supervision. Provides guidance concerning the purpose and scope of the Federal Reserve's supervision of financial holding companies, with particular emphasis on working with other relevant supervisors and regulators.

- SR 00-14: Enhancements to the Interagency Program for Supervising the U.S. Operations of Foreign Banking Organizations. Discusses additional steps that are being taken to further refine the interagency risk-focused supervision program for the U.S. operations of foreign banking organizations.

The LCBO program continues to develop and to be refined in response to changes in the industry. Senior management within the Federal Reserve System meet regularly to review the LCBO program and to strengthen it, where possible.

2. For more detail, see text note 11 .
Changes in the environment in which banking organizations operate have had a very substantial impact on the way they are managed and, in turn, have necessitated changes in the way they are supervised. It became clear that the traditional process of examining banking organizations once a yearfocusing mostly on their stock of assets at a fixed point-would no longer be an effective way to evaluate the condition of many banking organizations. The Federal Reserve responded to this situation in the 1990s by developing a program of risk-focused supervision. Various aspects of risk-focused supervision have been communicated in a series of letters on policy guidance starting in 1995 (see box "Key Milestones in Risk-Focused Supervision"). The LCBO supervision program, which was formally established in 1999, is essentially an intensive application of risk-focused supervision to the largest, most complex banking organizations. These are the institutions in which change is most dramatic, with respect both to the impact of change and the speed with which changes in the organizations' risk profiles can 
occur (see box "Criteria for Inclusion in the LCBO Program"). Generally, by paying special attention to LCBOs, supervisors aim to minimize significant adverse effects on the public, on financial markets and the financial system in the United States and abroad, and on taxpayers, who provide the ultimate resources behind the bank safety net.

\section{Criteria for Inclusion in the LCBO Program}

A number of measures are employed as guidelines for determining whether a particular banking organization should be included in the LCBO supervision program. These measures take into account the size of the organization, the extent of international operations, participation in large-value payment and settlement systems, and the extent of custody operations, fiduciary activities, and trading activities. For foreign organizations with a significant U.S. presence, these measures are assessed for U.S. operations as well as for the global organization. Measures that are considered include the following:

- Total assets

- Size of off-balance-sheet exposures

- Activity in derivatives markets

- Trading assets and trading revenue

- Foreign assets and foreign deposits

- Funding from market (non-deposit) sources

- Securities borrowed and securities lent

- Income from fiduciary activity

- Mutual fund sales and mutual fund fee income

- Revenue earned in mortgage markets

- Assets under management

- Activity in payment systems

- Involvement in securities settlements

- Geographic scope of operations

- Merchant banking activities and proprietary investments

No single factor qualifies or disqualifies an organization from being considered an LCBO. It is also important to note that the population of LCBOs is fluid and can change as a result of developments affecting a banking organization or changes in the industry as a whole. In particular, the number of LCBOs can change rather quickly as a result of mergers and acquisitions. Since the establishment of the LCBO program, the number of institutions that are considered LCBOs has been in the range of twenty-five to thirty companies. In addition, there are a number of banking organizations that do not meet enough of the criteria to be considered LCBOs but have sufficient size or complexity in some of their activities to be covered by the program to a certain extent.

\section{Overview of the LCBO Program}

The fundamental goals of the Federal Reserve's supervisory process for LCBOs are to maintain an accurate and current assessment of each banking organization's financial and managerial strength and to respond in a timely fashion to any emerging problem. There are a number of important elements that together define this program (see box "Comparison of Traditional Bank Examinations with Risk-Focused Supervision for LCBOs"):

- The program places strong emphasis on understanding and evaluating each institution's internal risk-management processes and control infrastructures.

- Each LCBO is assigned a team of Federal Reserve supervisors, who conduct an ongoing supervisory program based on the risks that have been identified in the organization's operations.

- Small teams with technical expertise on such issues as credit-risk modeling, payment systems, and information technology are available to supplement individual LCBO teams.

- The Federal Reserve's assessment of the banking organization's risk profile, as well as the corresponding plan for supervision of the institution, is updated quarterly, or more frequently as warranted, taking into account market developments

- The program stresses the development of relationships with the management of the banking organization at various levels through regular and frequent communications.

- The banking organizations that are covered by the LCBO program are viewed not just individually but also as a group to identify common or emerging weaknesses that have the potential to become more serious or to become systemic problems.

Regardless of how their business lines are managed, most LCBOs operate through a variety of legal entities that fall under the jurisdiction of different licensing and supervisory authorities, requiring a high level of information sharing and coordination among relevant supervisory agencies. For example, because a number of U.S.-headquartered LCBOs have lead banks with national bank charters, the Federal Reserve and the Office of the Comptroller of the Currency, the supervisor for national banks, cooperate closely in the supervision of these banking organizations. This collaboration among supervisory agencies both facilitates understanding the risk profile of a banking organization as a whole and 


\section{Comparison of Traditional Bank Examinations with Risk-Focused Supervision for LCBOs}

\begin{tabular}{l|l}
\hline \multicolumn{1}{c|}{ Traditional Bank Examinations } & \multicolumn{1}{c}{ Risk-Focused Supervision for LCBOs } \\
\hline $\begin{array}{l}\text { Supervisory process is focused on a single point in time } \\
\text { and is rarely continuous unless there is a crisis. }\end{array}$ & $\begin{array}{l}\text { Supervisory process is continuous and is more tuned } \\
\text { to market developments. }\end{array}$ \\
$\begin{array}{l}\text { Examinations are generally staffed locally. } \\
\text { Institutions are assigned designated supervisory teams. } \\
\text { The teams are supplemented with specialists, who may } \\
\text { be drawn from across the Federal Reserve System. }\end{array}$ \\
$\begin{array}{ll}\text { Significant emphasis is placed on valuation of assets. } & \begin{array}{l}\text { Focus is on risk-management processes and control } \\
\text { systems. } \\
\text { Tialogue with management is mostly related to } \\
\text { examination findings unless there is a crisis. }\end{array} \\
\text { Thanagement. } \\
\text { Supervisory process includes more interaction with line } \\
\text { management of business activities and risks. }\end{array}$ \\
$\begin{array}{l}\text { Program includes business line and functional reviews } \\
\text { that incorporate identification of best practices. }\end{array}$ \\
\hline
\end{tabular}

reduces the burden of the supervisory process on that organization.

\section{BASIC FRAMEWORK \\ FOR RISK-FOCUSED SUPERVISION}

The basic framework for risk-focused supervisionthe program that the Federal Reserve applies to all complex banking organizations with more than $\$ 1$ billion in assets (discussed in SR 97-24) - consists of four principal activities that are carried out in a continuous cycle. ${ }^{6}$ These are (1) gaining an understanding of the institution through a detailed risk assessment; (2) developing the supervisory plan; (3) executing the supervisory plan and reporting the results; and (4) determining and communicating the overall condition of the banking organization and addressing supervisory concerns.

\section{Formulating the Risk Assessment}

The process of understanding an institution and assessing its risks combines a "bottom-up" analysis of significant business lines-including reviews of sampled individual credits, exposures, and transactions-with a "top-down" look at the broad policies, procedures, and controls with which the banking organization identifies and manages risks

6. The Federal Reserve has also developed a program for riskfocused supervision of community banks. That program is discussed in SR 97-25. company-wide. Using both approaches, examiners evaluate six major types of risk-credit, market, liquidity, operational, legal, and reputational (see box "Major Risk Categories"). For significant business lines, examiners prepare an activity risk matrix by evaluating the inherent risk undertaken by the business line with respect to the six major risk categories and then evaluating whether that risk is low, moderate, or high. They then assess the strength of the organization's systems for managing those risks, evaluating them as strong, acceptable, or weak. Riskmanagement systems include oversight by the board of directors and senior management; policies, procedures, and limits; internal risk review and management information systems; and internal control processes.

The institution-wide risk assessment is also prepared along the lines of the six major types of risk and includes a composite risk assessment. Examiners judge the level of each risk-high, moderate, or low - and the direction of risk - increasing, stable, or decreasing. In arriving at these assessments, examiners incorporate their evaluations of corporate-wide processes for identifying, measuring, monitoring, and controlling the six major types of risk, as well as their assessments of the risk profiles of significant business lines.

\section{Developing the Supervisory Plan}

The completion of the institution-wide risk assessment leads to the development of a comprehensive 


\section{Major Risk Categories}

Credit risk arises from the potential that a borrower or counterparty will fail to perform on an obligation.

Market risk is the risk to a financial institution's condition resulting from adverse movements in market rates or prices, such as interest rates, foreign exchange rates, or equity prices.

Liquidity risk is the potential that an institution will be unable to meet its obligations as they come due. It may occur because an institution cannot liquidate assets or obtain adequate funding (referred to as funding liquidity risk) or because it cannot easily unwind or offset specific exposures without significantly lowering market prices because of inadequate market depth or market disruptions (referred to as market liquidity risk).

Operational risk arises from the potential that inadequate information systems, operational problems, breaches in internal controls, fraud, or unforeseen crises will result in unexpected losses.

Legal risk arises from the potential that unenforceable contracts, lawsuits, or adverse judgments will disrupt or otherwise negatively affect the operations or condition of a banking organization.

Reputational risk is the potential that negative publicity regarding an institution's business practices, whether true or not, will cause a decline in the customer base, costly litigation, or revenue reductions.

supervisory plan for the banking organization. The supervisory plan outlines both the ongoing monitoring and examination activities that are to be carried out over the next twelve months and the resources required for these activities. The activities that make up the supervisory plan are a direct reflection of the areas of significant risk identified in the risk assessment. The risk assessment is updated whenever significant new information is obtained, and the supervisory plan, in turn, is updated to reflect any significant changes in an institution's risk assessment.

The supervisory plan is developed in close coordination with other relevant supervisors and also takes into account the findings of internal audits and independent reviews. The coordination inherent in the planning process is designed to utilize, to the extent feasible, work done by others to avoid duplication of effort and unnecessary regulatory burden on the institution.

\section{Executing the Supervisory Plan}

Executing the supervisory plan entails a combination of ongoing analysis and monitoring activities, preexamination analysis, and examination activity, which generally includes some level of transaction testing. ${ }^{7}$ Ongoing analysis and monitoring activities may include the review of policies and procedures, of internally generated management information reports and regulatory filings, of audit findings, and of other documents. Given the wide range in size and complexity of the institutions covered under the basic risk-focused framework, examination work can vary from an annual examination that is focused on significant risk areas to a series of reviews targeted at functional areas or business lines that are conducted throughout the year. While carrying out their work, examiners refer to supervisory manuals as well as supplemental guidance. The results of these supervisory assessment activities are detailed in various written documents, including reports, letters to the management of the institution, and, in some cases, memoranda that discuss the findings of reviews conducted at a number of institutions.

\section{Determining and Communicating the Condition of the Institution}

The final step in the ongoing process of basic riskfocused supervision is making a judgment about the overall condition of the banking organization, communicating that condition to the company's management, and addressing any supervisory concerns that have been identified. An overall assessment of the institution's condition is prepared and sent to the institution at least annually. Management is requested to respond as to how it plans to address any areas of supervisory concern that have been brought to its attention in the assessment. Any necessary supervisory measures for remedial action are also prepared at this stage.

\section{APPLICATION OF RISK-FOCUSED SUPERVISION TO LCBOS}

\section{Increased Emphasis on Internal Systems and Controls for Managing Risk}

The size, complexity, and rapidly changing risk profiles of LCBOs make evaluation of their condition as

7. Transaction testing involves the review of individual transactions, such as loans, derivatives contracts, or investments, to assess the adequacy and consistency with which the institution's policies and procedures are applied. 
of a fixed point in time extremely difficult and, at the same time, less meaningful than for smaller, less complex institutions. Therefore, for LCBOs, the supervisory process places even greater emphasis on evaluating the organizations' own systems for managing risk as well as on evaluating their internal control processes.

Nevertheless, transaction testing remains an important element in the assessment of these banking organizations' risk-management systems. Examiners also evaluate the sufficiency with which banking organizations stress test their portfolios in the process of managing risk. ${ }^{8}$ Over time, as supervisors become satisfied with individual banking organizations' systems for classifying and measuring risk, they are expected to provide bank management with suggestions for further improvements in the systems based on industry-wide best practices, consistent with minimum standards for safety and soundness.

The Gramm-Leach-Bliley Act (GLBA) authorized qualifying bank holding companies to operate as financial holding companies (FHCs) and to engage in a diverse range of financial activities. The Federal Reserve now acts as "umbrella" supervisor for FHCs. The approach used by the Federal Reserve under the LCBO program is fully consistent with the process prescribed by GLBA for supervising FHCs. ${ }^{9}$ Umbrella supervision under GLBA reflects the reality that the risks associated with financial activities generally cut across legal entities and business lines and that, in fact, most large and sophisticated financial services companies take a consolidated, or organization-wide, approach to managing their risks. The umbrella role requires the Federal Reserve to understand FHC's corporate-wide systems and controls for managing risk and to keep primary bank supervisors and other relevant supervisors advised of any evolving problems in these areas that may affect the entities they supervise and regulate.

\section{Assignment of a Designated Team}

One of the essential elements of the supervisory program for LCBOs is the assignment of a full-time team of Federal Reserve supervisors to each banking organization. This designated team is responsible for developing and maintaining the Federal Reserve's supervisory plan for the banking organization and for

8. For example, the banking organization might conduct stress tests by revaluing portions of its portfolio based on a hypothetical increase in interest rates or a hypothetical change in exchange rates.

9. SR 00-13 Framework for Financial Holding Company Supervision provides guidance concerning the purpose and scope of the Federal Reserve's supervision of FHCs. coordinating all supervisory activity related to it. In its effort to accomplish this goal, the team must maintain a high level of knowledge about the banking organization and its strategies, organizational structure, risk-management systems, and control policies.

Each designated team is headed by a very senior examiner or Reserve Bank official-the "central point of contact," or CPC, for the institution. The CPC serves as the Federal Reserve's primary day-today contact for a particular LCBO and coordinates the development and execution of the supervisory strategy for the institution.

The designated team generally comprises four to ten seasoned examiners and analysts. Team members typically have broad-based knowledge and experience in banking and skill sets that are particularly relevant to the risk profile and major activities of the banking organization. The work of the designated team is supplemented as necessary with specialists in technical areas such as modeling credit risk and market risk, payment systems, and information technology. Staffing for the designated team is directed by the Reserve Bank that has responsibility for leading the Federal Reserve's supervisory program for the banking organization. A team may include members from more than one Reserve Bank, and specialists may also be drawn from across the System.

\section{Maintaining Information Flows}

Complex banking organizations typically measure and manage consolidated risk by individual customer; by major line of business; by category of risk, such as credit risk or market risk; by industry and geographic sector; and within distinct legal entities. The supervisory team for an LCBO looks at how the institution measures, monitors, and controls risk in each of these areas. The team is able to maintain its ongoing understanding of these risks in part through the establishment of regular information flows from a variety of sources. Included are internal management information reports from the banking organization as well as internal and external audit reports, regulatory filings, publicly available information, and information from other supervisors. Also included in the process are regular discussions with the management of the banking organization as well as discussions with other supervisory authorities responsible for that banking organization. With respect to internal management information reports, some of the largest banking organizations are increasingly providing direct on-line access to this information for the supervisory team. 
The information-gathering portion of the ongoing supervision process is supported by an appropriate degree of verification through examinations or targeted reviews of specific business lines. Such activities include testing of processes, procedures, and controls, as well as a degree of transaction testing and analysis that reflects the level of risk in the area being reviewed and whether concern exists about the institution's ability to manage risk in that area. Targeted reviews of business lines are generally conducted in the following types of circumstances:

- When the supervisory team determines that a business line has high inherent risk that is not well controlled or when little information is available to the team on the operational controls

- When the business line is new, has undergone significant expansion, or is significant in terms of revenue and capital contribution but has not been reviewed for an extended period

- When the business line has experienced significant operational problems.

The objective of targeting business lines for review is to assess the adequacy of controls on activities undertaken in these business lines and to assess more fully their risk to the corporation.

\section{Coordinating with Other Supervisors}

Before the development of risk-focused supervision, the style of communication among supervisors on matters pertaining to an individual institution primarily involved ad hoc contact. Such contact included exchange of examination reports, sharing of information related to specific problem situations, and coordination when special examination work was necessary to obtain additional information regarding a problem situation. The supervisors involved in this traditional pattern of communication included the Office of the Comptroller of the Currency (OCC), the Federal Deposit Insurance Corporation, the Office of Thrift Supervision, state banking agencies, and foreign bank supervisors.

Several authorities are usually involved in supervising various parts of the operations of LCBOs, both within the United States and abroad. As these banking organizations have evolved, ongoing contact among the supervisors of the principal affiliates within a banking organization has become particularly important. This contact is necessary not only to avoid duplicative work by supervisors and excessive burden on the institution but also to provide the respective parties with the benefit of the perspective of their counterparts.

\section{Coordinating with Other Primary Supervisors}

This need for the exchange of information is particularly important when the lead bank of an LCBO has a primary supervisor other than the Federal Reserve. The lead bank typically plays an integral role within these dynamic banking organizations. In addition, systemic risk is associated with the potential disruption of the operations of large banks. Thus, the Federal Reserve needs to know more about the activities within large insured depository institutions than can be derived from public information or from the reports of the primary bank supervisor, and it also needs to have more than ad hoc contact with the primary bank supervisor. Similarly, the primary bank supervisor needs information about the activities of a bank's parent company and its nonbank affiliates to be aware of, and address as necessary, threats to the soundness of the bank that may arise from elsewhere in the consolidated organization.

As noted earlier, the Federal Reserve cooperates routinely with primary bank supervisors in preparing supervisory plans for LCBOs. The Federal Reserve takes into account work that has been done by the primary supervisor in identifying those areas that it wants to focus on at a banking organization. In addition, there are times when examiners from both the Federal Reserve and the primary bank supervisor participate in an examination. For example, examiners from both the Federal Reserve and the OCC may participate in a review of an organization's internal audit process. Such an examination is normally under the lead of one of the agencies, and, ordinarily, only one report or memorandum is prepared.

\section{Coordinating with Functional Regulators}

Because many LCBOs have become financial holding companies, they are in a position to expand further the range of activities they engage in through nonbank subsidiaries. Therefore, functional regulators have been added to the mix of regulatory counterparts with which effective communication and cooperation needs to take place. Functional regulators include the Securities and Exchange Commission, the Commodities Futures Trading Commission, the National Association of Securities Dealers, and constituents from the National Association of Insurance Commissioners. In its role as the umbrella 
supervisor of financial holding companies, the Federal Reserve must coordinate its activities with these functional regulators and work with them to understand the risk profiles of the individual regulated entities and their relation and importance to an FHC's overall risk profile.

\section{Coordinating with Foreign Supervisors}

In the international sphere, the Federal Reserve has been working with its counterparts in various countries around the world to strengthen communication and cooperation in the supervision of banking organizations that operate across borders. These efforts at collaboration have intensified in recent years and now take place in a variety of international settings, as well as on a bilateral basis between supervisors with respect to individual banking organizations (see box "Special Aspects of Supervising Large Foreign Banking Organizations"). One example of a multilateral effort is the Basel Committee on Banking Supervision, in which supervisors from member countries meet to discuss important issues and formulate guidelines to improve and refine the process of banking supervision globally.

\section{Portfolio Approach}

Evaluating activities of banking organizations across institutions to identify trends and ensure consistency in supervisory treatment has long been a practice among supervisors. ${ }^{10}$ The LCBO program builds upon this practice by emphasizing comparative analysis of LCBOs with similar business lines, characteristics, and risk profiles. This portfolio approach to supervision serves to identify "outliers" among LCBOs with respect to risk profiles and riskmanagement techniques. By using this approach, supervisors are able not only to continue ensuring

10. An example is the Shared National Credit program, in which the bank supervisory agencies review large syndicated loans (more than $\$ 20$ million) annually to provide an efficient and consistent review and classification of any loan or loan commitment shared by three or more supervised institutions.

\section{Special Aspects of Supervising Large Foreign Banking Organizations}

Foreign banking organizations (FBOs) have a sizable presence in the United States, accounting for about 20 percent of the assets held by banking organizations located or operating in the United States. ${ }^{1}$ Some of the largest FBOs are also among the largest participants in U.S. financial markets. Because of their size and complexity both on a global level and in terms of their U.S. operations, large FBOs account for approximately one-third of the banking organizations in the LCBO program.

U.S. bank supervisory agencies operate as "host country" supervisors for FBOs. As a result, although they have full access to information concerning the U.S. operations of FBOs, they do not have the same level of access to information on FBOs' consolidated operations and riskmanagement systems as the home country supervisors do. Therefore, U.S. supervisors focus particular attention on evaluating an FBO's consolidated financial condition, its capital adequacy, and its general ability to support its U.S. operations. In this regard, U.S. supervisors apply several specific criteria to assess an FBO's ability to support its U.S. operations, including measures related to financial and managerial soundness, to corporate governance, and to transparency. ${ }^{2}$

1. Total assets held by foreign banking organizations include total assets of U.S. bank holding companies or financial holding companies held by those foreign institutions, as well as total assets of branches, agencies, Edge corporations, direct nonbank subsidiaries, and commercial lending companies held by them.

2. The Federal Reserve, along with other banking agencies, has in place a program for the coordinated supervision of FBOs, which outlines how
For FBOs that are part of the LCBO supervision program, the program's risk assessments are prepared specifically for the U.S. operations. However, U.S. supervisors need to have a sufficient understanding of an FBO's global risk-management and internal control systems in order to evaluate the manner in which those systems are applied with respect to oversight and control of its U.S. operations. U.S. supervisors are often able to obtain much of this information from FBO management based in the United States. However, in many cases the centralized nature of banking organizations' management of certain business lines or control functions may necessitate discussions with corporate management at the FBO's headquarters.

A core element of the LCBO program as applied to FBOs is communication with home country supervisors. In periodic meetings and discussions, U.S. supervisors seek the views of the home country supervisors on developments in the home country financial system generally and with respect to individual FBOs. U.S. and home country supervisors share information, as appropriate, contained in risk assessments and supervisory plans and obtained in examinations of U.S. operations of FBOs. When follow-up supervisory action is necessary, U.S. and home country supervisors work together closely in the development and implementation of the supervisory action.

these measures should be evaluated. See SR 00-14 Enhancements to the Interagency Program for Supervising the U.S. Operations of Foreign Banking Organizations (available at www.federalreserve.gov/boarddocs/srletters). 
consistency in the supervision of institutions with similar businesses and risk profiles but also to compare risk-management practices within the industry. In a broader sense, supervisors are given an improved framework for discerning industry trends, which can be particularly useful in informing policymakers.

In the development of the LCBO program, there have been a number of structured efforts to improve portfolio analysis of LCBOs. Two of the most important have been Coordinated Supervisory Exercises (CSEs) and the establishment of competency centers and knowledge centers. Through CSEs, supervisors develop comparative analyses of risk-management processes governing specific business activities or functional areas, deepen their understanding of inherent risk in specific business activities, develop examiner expertise, and identify gaps or weaknesses in existing Federal Reserve System policies and procedures. For each CSE, a team is formed that typically has members from several Reserve Banks as well as staff from the Federal Reserve Board. CSEs can take various forms but usually involve examination work at a number of LCBOs, which are selected based on their involvement in the business activity or control function being reviewed. Once the project is completed, participants in a CSE prepare a report on the results and findings and distribute it within the community of relevant supervisors. In addition, the aggregate findings are discussed with the banking organizations that were included in the CSE.

The establishment of competency centers and knowledge centers, which are housed at designated Reserve Banks, arose out of a need to develop and maintain Federal Reserve System expertise in specific technical areas in an efficient manner. At this time, competency centers have been established for two areas-venture capital activities and capital management processes. ${ }^{11}$ One knowledge center has been established with respect to insurance activities. These centers assist examiners and other supervisory staff in keeping abreast of the most recent developments in their respective areas. In addition, competency centers maintain teams of specialists in their respective areas that are available to participate in examinations in other Federal Reserve Districts.

\section{Market Discipline}

The idea that financial markets can provide useful discipline to U.S. banking organizations is not new.

11. These processes include sophisticated techniques used to model the specific amount of capital necessary to support certain activitiesoften referred to as "economic" capital.
However, as non-core funding-that is, funding based on uninsured deposits-now represents a higher percentage of total funding than in the past, particularly for LCBOs, it is important that market participants play a greater role in the supervision of these banking organizations. The need for market discipline - and its prerequisite, public disclosure - is heightened because the unusual size and complexity of LCBOs requires either more burdensome and detailed supervision and regulation or incentives from other sources to ensure safe and sound banking operations. Discipline of LCBOs and other banking organizations by the market can complement supervision by reducing excessive risk-taking, by alleviating some of the moral hazard that exists with a federal safety net, and, it is hoped, by decreasing the level of supervision that would otherwise be necessary. ${ }^{12}$

Market discipline works through changes in access to funds and changes in risk premiums as banks take on or shed risk or engage in certain types of transactions. Market discipline can function directly, for example, if the cost of funding for a banking organization rises as its risk-taking increases; or indirectly, as market participants and bank supervisors observe prices of the company's financial instruments (including equity shares and various types of debt) to assess whether the risk profile has increased and then take appropriate action. Two particular approaches to market discipline appear to be most promising, particularly for LCBOs: increased public disclosure and issuance of subordinated debt by the companies. ${ }^{13}$

More transparent balance sheets and the disclosure of additional information about a banking organization's risks are beneficial to shareholders, debt holders, and the market in general. Expanding this type of disclosure is one strategy for improving market discipline. To be sure, most LCBOs already disclose a considerable volume of information to market participants, and, indeed, there is ample evidence that market discipline now plays a role in affecting their behavior. Nonetheless, the scale and clarity of disclo-

12. The term "moral hazard" applies to instances in which an economic agent's risk-taking is affected by the fact that the agent faces zero or reduced costs from a negative outcome of a risky action but receives full gains from a positive one. For example, if creditors of a banking organization know that deposit insurance will protect them from losses if it fails, then they have few incentives to protect against a deterioration in its financial condition.

13. In 1999, a Federal Reserve task force sponsored the publication of staff studies on these two subjects: Federal Reserve System Study Group on Disclosure, Improving Public Disclosure in Banking, Staff Studies 173 (Board of Governors of the Federal Reserve System, March 2000); and Federal Reserve System Study Group on Subordinated Notes and Debentures, Using Subordinated Debt as an Instrument of Market Discipline, Staff Studies 172 (Board of Governors of the Federal Reserve System, December 1999). 
sures is better at some institutions than at others and, on average, could be considerably improved.

One particularly useful element of increased public disclosure is the reduced tendency for market participants to be surprised by sudden adverse news. If information is released on a more consistent basis, the reporting of unfavorable news is less likely to result in large market movements, which might have systemic implications. Supervisors are engaged in a dialogue with the banking industry to identify those areas in which expanded public disclosure would be most useful. In that regard, a private-sector working group recently issued recommendations for more frequent public disclosure of financial information by banking and securities organizations. Among its recommendations, the group said that market risk information previously disclosed annually should be disclosed quarterly; that the content of market risk disclosures should be improved; and, that additional credit risk information on wholesale credit exposures should be made available quarterly. The group also noted that public disclosures should vary among institutions to reflect legitimate differences in internal management processes and that disclosure practices should change in step with innovations in firms' risk-management and measurement practices. ${ }^{14}$

The second strategy that may hold considerable promise for augmenting market discipline is to require banks to issue minimum amounts of subordinated debt to unrelated parties. Subordinated debt holders have an interest in discouraging excessive risk-taking because their claims are both long-term and junior to all depositors and to any senior debt holders. Subordinated debt holders share in very limited ways in potential gains made by a company but are exposed to considerable risk if it encounters financial difficulty. In this respect, their risk preferences can resemble those of banking supervisors. By raising a company's cost of funds, subordinated debt holders can send a direct signal that excessive risktaking is not desired. However, as documented in a recent report to the Congress by the Treasury and

14. The Working Group on Public Disclosure, established in April 2000 by the Federal Reserve Board, was composed of representatives of eleven banking and securities firms. The working group's recommendations were announced in a joint press release by the Federal Reserve Board, the OCC, and the U.S. Securities and Exchange Commission, dated January 11, 2001, that is available on the Board's web site at www.federalreserve.gov/boarddocs/press/general/2001. the Federal Reserve Board, a number of uncertainties need to be clarified before a mandatory subordinated debt policy would be judged desirable. ${ }^{15}$ These uncertainties include how best to interpret changes in debt spreads, whether changes in other regulatory policies, such as improvements in risk-based capital rules, will make mandatory subordinated debt unnecessary, and whether the bank or its holding company parent should issue the debt.

\section{BENEFITS OF THE LCBO SUPERVISION PROGRAM}

To date, there have been some recognizable benefits from the implementation of the LCBO program. First, supervisors are able to maintain on a more consistent basis a deeper understanding of the risk profiles, financial performance, and relative strength of the banking organizations in the program. Information exchanges-both with banking organizations and with other supervisors-are more frequent and open at all levels than in the past. As a result of ongoing monitoring and coordination efforts, the Federal Reserve becomes aware more quickly of emerging problems and is able to work with banking organizations and other supervisors, as appropriate, to take whatever steps may be necessary to address these issues. Having a more complete and continuous flow of information also helps supervisors to gauge earlier the effect of potentially adverse events on banking organizations and on the financial system in general.

An additional benefit of the program is the perspective that has been gained on risk-management practices across the industry. This perspective enables supervisors to provide recommendations to banking organizations with respect to strengthening of riskmanagement processes. These recommendations are based on a greater understanding of industry-wide best practices, consistent with minimum standards for safety and soundness, than was generally available to supervisors in the past.

15. Under GLBA, the U.S. Treasury and the Federal Reserve Board were required to prepare a report to the Congress on the feasibility and desirability of a mandatory subordinated debt policy for certain depository institutions and their holding companies. This report, The Feasibility and Desirability of Mandatory Subordinated Debt, was submitted to the Congress in December 2000 and is available on the Board's web site at www.federalreserve.gov/boarddocs/RptCongress/. 